\title{
The distribution of water in the continental lithospheric mantle and its implications for the stability of continents
}

\author{
XIA QunKe* \& HAO YanTao \\ CAS Key Laboratory of Crust-Mantle Materials and Environments, School of Earth and Space Sciences, University of Science and Technology of \\ China, Hefei 230026, China
}

Received January 14, 2013; accepted May 14, 2013; published online July 11, 2013

\begin{abstract}
The lithospheric mantle is one of the key layers controlling the stability of continents. Even a small amount of water can influence many chemical and physical properties of rocks and minerals. Consequently, it is a pivotal task to study the distribution of water in the continental lithosphere. This paper presents a brief overview of the current state of knowledge about (1) the occurrence of water in the continental lithospheric mantle, (2) the spatial and temporal variations of the water content in the continental lithospheric mantle, and (3) the relationship between water content and continent stability. Additionally, suggestions for future research directions are briefly discussed.
\end{abstract}

water, nominally anhydrous minerals, continental lithospheric mantle, continent stability

Citation: Xia Q K, Hao Y T. The distribution of water in the continental lithospheric mantle and its implications for the stability of continents. Chin Sci Bull, 2013, 58: 3879-3889, doi: 10.1007/s11434-013-5949-1

The lithospheric mantle is the lowermost part of continental plates; its viscosity contrast with the underlying asthenosphere induces positive buoyancy and maintains its longterm stability. It is pivotal to investigate the formation and evolution of the continental lithospheric mantle when studying the formation, destruction and evolution of continents, and doing so is a prerequisite to understanding the processes that have occurred in the Earth's interior.

Hydrogen that is structurally bound to other ions (mainly oxygen) in minerals is traditionally referred to "water" in earth sciences and is calculated as $\mathrm{H}_{2} \mathrm{O}$ by weight. Its existence, even at trace levels (ppm level), can disproportionately change many chemical and physical properties (e.g. wave velocity, electronic conductivity, rheology, thermal conductivity, optical properties, melting temperature, ion diffusion) of minerals [1-13]. Consequently, water affects the chemical, physical and dynamic processes of rocks and their involved mantle domains, such as the relative movement of continental plates and the genesis and evolution of intraplate magmas [7,14-24]. Additionally, the amount of water in the

\footnotetext{
*Corresponding author (email: qkxia@ustc.edu.cn)
}

continental lithospheric mantle is tightly related to its viscosity and stability [23,25-28]. Understanding the distribution of water in the continental lithospheric mantle, therefore, is an important part of studying its formation and evolution.

\section{Hydrogen species in the continental litho- spheric mantle}

There are three types of hosts for water in the continental lithospheric mantle: (1) fluid inclusions; (2) hydrous minerals; and (3) nominally anhydrous minerals (NAMs; i.e. minerals without $\mathrm{H}$ in the ideal chemical formula, such as olivine, pyroxene, garnet, and feldspar).

Although fluid inclusions in peridotite minerals may contain a certain amount of water when they are captured, subsequent dehydration via exchange with host minerals leaves dehydrated and $\mathrm{CO}_{2}$-dominated fluids [29]. Therefore, the contribution of fluid inclusions in the total amount of water in the lithospheric mantle is small.

Hydrous minerals, such as amphibole, phlogopite and 
apatite, may be present in lithospheric mantle by melt/fluid metasomatism [30], but the premise of the formation of these minerals is the strong enrichment of $\mathrm{K}, \mathrm{Na}, \mathrm{P}, \mathrm{F}, \mathrm{Cl}$, etc., and therefore only occurs accidentally.

The continental lithospheric mantle consists dominantly of peridotites (i.e. diamond-, garnet-, spinel- and plagioclase-facies) with minor pyroxenites and eclogites. The main constituent minerals are olivine (ol), orthopyroxene (opx), clinopyroxene (cpx), garnet (grt), spinel (sp) and plagioclase (plag). Although these are "nominally anhydrous minerals", they can contain $\mathrm{H}$ in the crystal defects, in the form of $\mathrm{OH}$ or $\mathrm{H}_{2} \mathrm{O}$ (the so-called structure $\mathrm{H}_{2} \mathrm{O}$ ), and have $\mathrm{H}_{2} \mathrm{O}$ contents $\left(\mathrm{H}_{2} \mathrm{O}\right.$ wt., hereafter the same $)$ ranging from a few to thousands of ppm [27,31,32]. Although the absolute content of structure water in NAMs is not as high as in the hydrous minerals, NAMs constitute the largest water reservoir in lithospheric mantle when considering their volume and weight percentage. Overall, the main occurrences of $\mathrm{H}_{2} \mathrm{O}$ in the continental lithospheric mantle comprise mainly structure water hosted in crystal defects of NAMs in the form of $\mathrm{OH}$ or molecule $\mathrm{H}_{2} \mathrm{O}$.

The published data of $\mathrm{H}_{2} \mathrm{O}$ content in mantle minerals in the literature are obtained from the Fourier Transform Infrared Spectroscopy (FTIR) analysis and Secondary Ion Mass Spectroscopy (SIMS) analysis, though most of the data come from FTIR. The infrared absorption coefficient used for $\mathrm{H}_{2} \mathrm{O}$ content calculations varies in different literatures, but the generally accepted infrared absorption coefficients for ol, cpx, opx and grt are from Bell et al. [33,34]. If the Bell absorption coefficient was not used in the original study, all FTIR data involved in this paper were recalculated accordingly, using the same method as Peslier et al. [27].

\section{The distribution of water in the continental lithospheric mantle}

$\mathrm{H}_{2} \mathrm{O}$ behaves as an incompatible element in the melt system of mantle rocks, with a partition coefficient close to that of Ce [22,35]. Like other incompatible trace elements, the distribution of $\mathrm{H}_{2} \mathrm{O}$ in the continental lithospheric mantle is heterogeneous, both spatially and temporally. The discussion in this paper is based on the dataset of peridotite minerals because (1) peridotite is the dominant rock type of the continental lithospheric mantle and (2) the majority of the published data on the water contents of the continental lithospheric mantle is from minerals in peridotite xenoliths.

The host rocks for peridotite xenoliths are mainly kimberlites and alkali basalts. Previous studies have shown that both olivine and pyroxene in peridotite xenoliths hosted by kimberlites may have preserved the initial water contents of the mantle source in their cores, though their rims likely experienced a loss of $\mathrm{H}[27,31,36-38]$. In the peridotite xenoliths hosted by alkali basalts, the cores of cpx and opx can effectively preserve their initial water contents from the mantle source $[23,31,36,39-41]$; however, both the rims and cores of ol may experience $\mathrm{H}$ loss during the xenolith ascent $[23,37,42,43]$ and result in a low measured water content. Differences in the behaviors of ol and pyroxene may be related to a variety of factors [27]: (1) $\mathrm{H}$ in ol may partially exist in planar defects that are easier to diffuse out of the structural lattice, (2) ol is weaker than pyroxene and consequently deforms more easily, and (3) H-bond strength is weaker in ol than in pyroxene. The fact that olivines in peridotite xenoliths hosted by alkali basalts are more prone to diffusion compared to those hosted by kimberlite may be related to lower water content, higher temperatures, and a slower rate of ascent for basalts $[27,42,43]$.

There are two methods to calculate the whole-rock water content based on mineral water content and their modes: (1) using the measured $\mathrm{H}_{2} \mathrm{O}$ content of ol $[23,31,36]$ and (2) estimating the $\mathrm{H}_{2} \mathrm{O}$ content of ol from the measured $\mathrm{H}_{2} \mathrm{O}$ content of cpx and assuming a partition coefficient of 0.1 for ol/cpx $[40,44]$. Both experimental and natural observations show that, at the conditions of $P<3 \mathrm{GPa}$, the partition coefficient of $\mathrm{H}_{2} \mathrm{O}$ between ol and pyroxene is less than 0.1 $[22,27,31,36-38,45,46]$. For peridotite xenoliths hosted by alkali basalts, due to the rather low $\mathrm{H}_{2} \mathrm{O}$ content of ol compared to that of pyroxene, the difference between the wholerock water contents calculated using these methods is minor. For this reason, a direct comparison of $\mathrm{H}_{2} \mathrm{O}$ content of ol in peridotites (even if the data are from the core) hosted by alkali basalts with those hosted by kimberlites is futile, but comparisons of the $\mathrm{H}_{2} \mathrm{O}$ content in cores of pyroxenes and the calculated whole-rock $\mathrm{H}_{2} \mathrm{O}$ content of peridotites hosted by both magmas are credible. In this paper, the $\mathrm{H}_{2} \mathrm{O}$ content of ol, cpx, opx and whole rocks are all used when comparing peridotites hosted by kimberlites from different localities (Figure 1). In contrast, when comparing peridotite xenoliths hosted by alkali basalts with those hosted by kimberlites and comparing peridotite xenoliths hosted by alkali basalts from different localities (Figure 2), only the $\mathrm{H}_{2} \mathrm{O}$ content of opx, cpx and whole rocks are used.

\subsection{Heterogeneity of water contents in different types of the continental lithospheric mantle}

(1) Typical cratonic and off-cratonic lithospheric mantles. Examples of typical stable cratons are peridotite xenoliths hosted by kimberlites from the Kaapvaal craton in South Africa [27,31,36-38,47-49] and the Siberia craton in Russia [50,51]. The Siberia craton peridotites only include the $\mathrm{H}_{2} \mathrm{O}$ content data for ol and grt, and the pyroxene data are not available. The $\mathrm{H}_{2} \mathrm{O}$ contents of ol in peridotites from the Kaapvaal craton are 0-152 ppm (average $47 \mathrm{ppm}, N=52$ ), and those of ol in peridotites from the Siberia craton are 6-194 ppm (average $87 \mathrm{ppm}, N=13$ ). The $\mathrm{H}_{2} \mathrm{O}$ contents of garnets in peridotites from the Kaapvaal and Siberia cratons are 0-82 ppm (average $10 \mathrm{ppm}, N=56$ ) and $1-163 \mathrm{ppm}(\mathrm{av}-$ erage of $28 \mathrm{ppm}, N=40$ ), respectively. Both the range and 

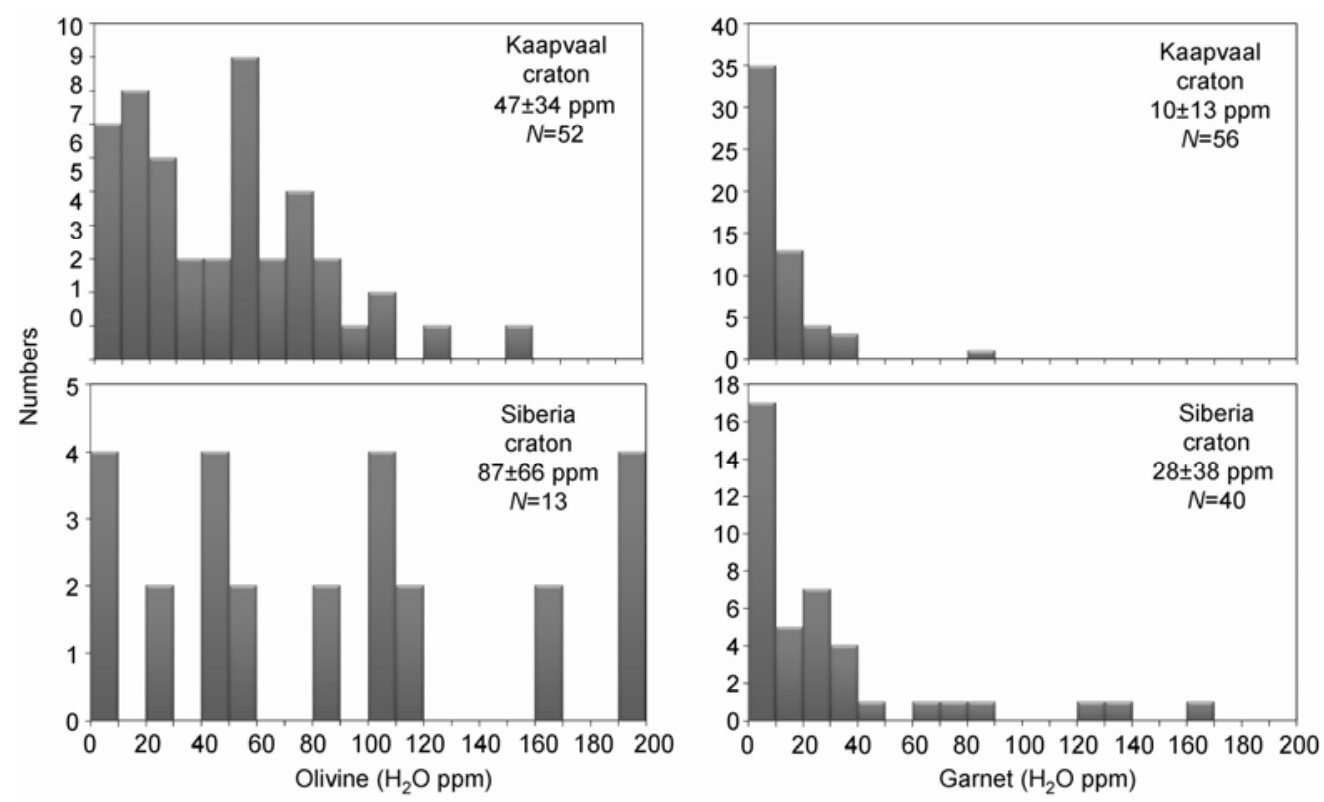

Figure 1 Comparison of the $\mathrm{H}_{2} \mathrm{O}$ content of olivine and garnet from the Kaapvaal and Siberia craton lithospheric mantle. Numbers in the figure are the average and standard deviation. Data for the Kaapvaal craton are from [27,31,36-38,47-49] and those for the Siberia craton are from [50,51].

frequency distribution of $\mathrm{H}_{2} \mathrm{O}$ contents of ol and grt from these two cratons are essentially identical (Figure 1); the difference in the average values could be derived from differences in sample numbers. In other words, the lithospheric mantles of the Kaapvaal and Siberia cratons have similar water contents based on the ol and grt data.

The $\mathrm{H}_{2} \mathrm{O}$ contents of cpx and opx in peridotites from the Kaapvaal craton are 149-399 ppm (average 283 ppm, $N=18$ ) and 41-460 ppm (average $188 \mathrm{ppm}, N=29$ ), respectively, and the calculated $\mathrm{H}_{2} \mathrm{O}$ content of whole rocks is 16-175 ppm (average $82 \mathrm{ppm}, N=29$ ).

The lithospheric mantle of the off-craton localities can be classified into two categories based on the age of formation: Proterozoic and Phanerozoic. The Proterozoic samples are garnet peridotite xenoliths hosted by kimberlites from Namibia [47], and only the $\mathrm{H}_{2} \mathrm{O}$ contents of garnets are available (1-22 ppm, averaged at $10 \mathrm{ppm}, N=26)$. The Phanerozoic samples are peridotite (mainly spinel-facies) xenoliths hosted by alkali basalts from the Basin and Range Province of North America [23,31,36,39,43,48,52,53], Pali-Aike of Chile [42], Eifel of Germany [48], Massif Central of France [36], Victoria of Australia [48], Greene Points and Baker Rocks of Antarctica [54], and Cape Verde of Africa [54]. The $\mathrm{H}_{2} \mathrm{O}$ contents of ol, cpx and opx in the Phanerozoic samples are 0-56 ppm (average $12 \mathrm{ppm}, N=36$ ), 5-550 ppm (average $282 \mathrm{ppm}, N=39$ ) and 9-246 ppm (average $110 \mathrm{ppm}$, $N=41$ ), respectively. The calculated whole-rock $\mathrm{H}_{2} \mathrm{O}$ content is $28-155 \mathrm{ppm}$ (average $99 \mathrm{ppm}, N=20$ ). Figure 2 shows that although the whole-rock $\mathrm{H}_{2} \mathrm{O}$ content of peridotites from the Kaapvaal craton has the same range as the typical off-craton samples, its peak and average values are lower and consistent with the overall "depleted" chemical composition of cratonic mantle [55,56].
(2) Thinning cratonic mantle-Colorado Plateau. The Colorado Plateau is an "isolated" island in the Cordillera orogen that has not experienced significant tectonic deformation. However, many studies have shown that since at least the Eocene, the lithospheric mantle in this area has thinned by several tens of kilometers and is continuing to thin [57-60]. Li et al. [23] analyzed the $\mathrm{H}_{2} \mathrm{O}$ content of minerals in peridotite xenoliths hosted by alkali basalts and minettes from the Colorado Plateau; they found that the $\mathrm{H}_{2} \mathrm{O}$ contents of cpx from 9 samples are 439-957 ppm (average $677 \mathrm{ppm}$ ) and those of opx from 10 samples are 274-402 ppm (average $344 \mathrm{ppm}$ ). These values are much higher than those from the Kaapvaal craton and other typical off-craton samples (Figure 2). In addition, the $\mathrm{H}_{2} \mathrm{O}$ contents of ol from 13 samples are 11-45 ppm (average of 20 ppm). Although ol grains have been shown to experience $\mathrm{H}$ loss upon the xenolith's ascent and produce the minimum estimates of $\mathrm{H}_{2} \mathrm{O}$ content for the mantle source, the highest $\mathrm{H}_{2} \mathrm{O}$ content of these olivines is still higher than the estimated values for olivines in the mid-ocean ridge basalts (MORB) source (10-30 ppm) [23]. The hydration of the lithospheric mantle of the Colorado Plateau has been ascribed to the subduction of the Farallon plate.

(3) Thinned "cratonic" mantle-North China craton. The North China craton (NCC) experienced a large-scale lithospheric thinning from late Mesozoic to early Cenozoic $[61,62]$, so peridotite xenoliths hosted by the Cenozoic basalts (<40 Ma) are from a thinned "cratonic" (the present $\mathrm{NCC}$ is not a craton) lithospheric mantle. The $\mathrm{H}_{2} \mathrm{O}$ contents have been obtained for $\sim 150$ peridotite xenoliths from 13 localities, covering both the eastern and western parts of the NCC $[40,41]$. The main feature is the strikingly low $\mathrm{H}_{2} \mathrm{O}$ content (Figure 2): olivine contains almost no water; the 

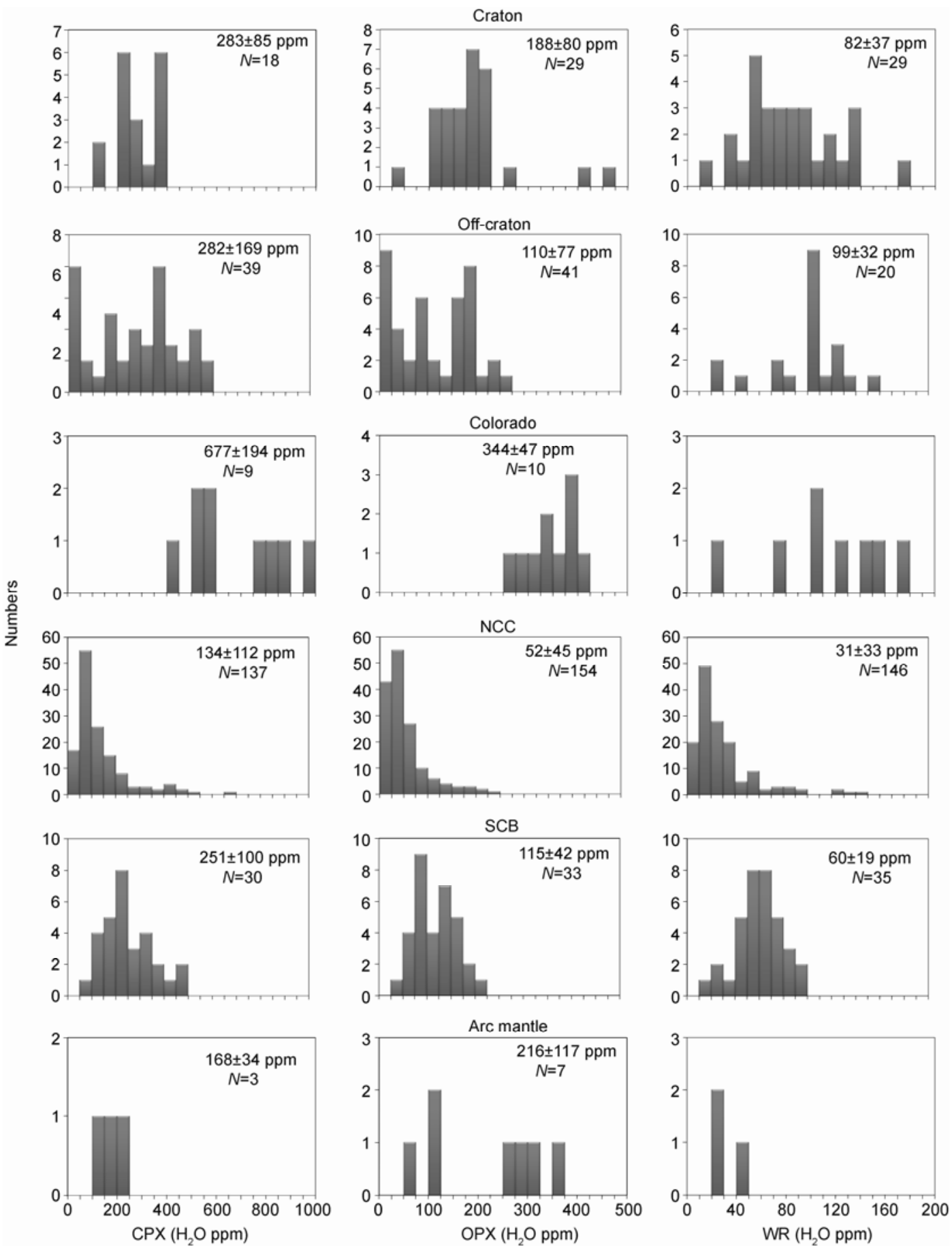

Figure 2 Comparison of the $\mathrm{H}_{2} \mathrm{O}$ content of peridotite from different types of lithospheric mantle. Numbers in the figure are the average and standard deviation. Due to the small sample size for the whole rock $\mathrm{H}_{2} \mathrm{O}$ content from Colorado and the back-arc $(N<10)$, there is no statistical significance, and we therefore did not calculate the average. Data for typical cratons are from [27,31,36-38,47-49], those for typical off-cratons are from [31,36,39,43,48, 52-55], those for the Colorado Plateau are from [23], those for the arc mantle are from [48], those for the NCC are from [28,40,41], and those for South China are from [75].

$\mathrm{H}_{2} \mathrm{O}$ contents of cpx and opx are usually $<200 \mathrm{ppm}$ (average $134 \mathrm{ppm}, N=137)$ and $<100 \mathrm{ppm}$ (average $52 \mathrm{ppm}, N=154)$, respectively; and the calculated $\mathrm{H}_{2} \mathrm{O}$ contents of whole rocks are usually $<50 \mathrm{ppm}$ (average $31 \mathrm{ppm}, N=146$ ). These values are not only lower than those of the typical craton and off-craton samples but also significantly lower than those of the MORB (50-200 ppm) [63-66] and oceanic island basalts (OIB) sources (300-1000 ppm) [64,66-70]. Unlike the mantle wedge peridotites in Simcoe of the United States, which have low $\mathrm{H}_{2} \mathrm{O}$ contents that account for the high oxidizing fluids (section 2.1(4) in Peslier et al. [39]), the low $\mathrm{H}_{2} \mathrm{O}$ contents of the NCC samples cannot be as- 
cribed to highly oxidized conditions but may instead be related to a thermal disturbance associated with lithospheric thinning (e.g. $\mathrm{H}_{2} \mathrm{O}$ loss by heating and/or extraction of $\mathrm{H}_{2} \mathrm{O}$ by melting). Therefore, the majority of the present lithospheric mantle of the NCC should comprise the relict ancient mantle after the lithospheric thinning event $[40,44]$. Some samples are from the localities close to deep faults, such as Nushan in Anhui Province, Beiyan in Shandong Province, and Yangyuan in Hebei Province, and are either located in the Tan Lu fault zone or the central part of the NCC, where mantle upwelling has been observed in geophysical studies. Some of these samples exhibit $\mathrm{H}_{2} \mathrm{O}$ contents and $\mathrm{Sr}-\mathrm{Nd}$ isotopic compositions similar to the MORB/OIB source and may represent the newly accreted mantle after thinning [40,44].

(4) Sub-arc lithospheric mantle. The sub-arc lithospheric mantle samples are peridotites from Simcoe in Washington (USA) [39] and Ichinomegata (Japan) [48] that had undergone subduction-related metasomatism, and the reported data are still limited. The $\mathrm{H}_{2} \mathrm{O}$ contents of ol from 14 samples from Ichinomegata are 13-26 ppm; those of opx from 4 samples are 270-350 ppm [48]. Olivine from 3 samples from Simcoe have almost no water; the $\mathrm{H}_{2} \mathrm{O}$ contents of opx, cpx, and the calculated whole-rock contents are 71-109 ppm, 140-205 ppm and 25-41 ppm, respectively [39] (Figure 2). The high water content of the island arc of Japan is consistent with the water-rich characteristics of island arcs [71-74], but the samples from Simcoe showed abnormally low $\mathrm{H}_{2} \mathrm{O}$ content. The data from the former is as expected from a water-saturated environment of mantle wedge under arcs; the data from the latter suggests metasomatism by water-poor fluids with very high oxygen fugacity, based on the anti-correlation between $\mathrm{H}_{2} \mathrm{O}$ content and oxygen fugacity $[27,39]$.

(5) South China Block. Yu et al. [75] reported the $\mathrm{H}_{2} \mathrm{O}$ contents of 35 peridotite xenoliths hosted by the Cenozoic basalts from 4 localities southeast of South China. The $\mathrm{H}_{2} \mathrm{O}$ contents of ol are 0-41 ppm (average $24 \mathrm{ppm}, N=5$ ), which are minimum values of the mantle source due to the possible $\mathrm{H}$ diffusion lost during ascent. The $\mathrm{H}_{2} \mathrm{O}$ contents of cpx and opx may have largely preserved the initial values in the mantle source and are 58-488 ppm (average of $251 \mathrm{ppm}$, $N=30$ ) and 38-213 ppm (average of $115 \mathrm{ppm}, N=33$ ), respectively. The $\mathrm{H}_{2} \mathrm{O}$ content of the calculated whole rocks is 12-94 ppm (average $60 \mathrm{ppm}, N=35$ ). Unlike the NCC samples, most samples from the South China block have wholerock $\mathrm{H}_{2} \mathrm{O}$ contents falling within the range of the MORB source; only a few samples exhibit the low $\mathrm{H}_{2} \mathrm{O}$ content that is characteristic of most samples from the NCC (Figure 2). In addition, peridotite xenoliths hosted by the Cenozoic basalts from the NCC and the South China block have no significant differences in rock types, mineral assemblages, major and trace elements and radiogenic isotope compositions [76-90]. Therefore, the significant difference of $\mathrm{H}_{2} \mathrm{O}$ content between peridotites in the two regions should not be due to processes of partial melting and mantle metasomatism but should be attributed to the differences of origin. The South China lithosphere mantle is mainly the newly accreted mantle from the asthenosphere with a few relict ancient portions, whereas the lithospheric mantle of the NCC consists dominantly of relict ancient mantle with some newly accreted asthenospheric mantle.

It is still not clear whether the South China block has experienced the similar lithospheric thinning event as the $\mathrm{NCC}$; if it has, the $\mathrm{H}_{2} \mathrm{O}$ content differences between the two regions suggest different mechanisms and processes of lithospheric thinning.

\subsection{Vertical variations of $\mathrm{H}_{2} \mathrm{O}$ content in the continen- tal lithospheric mantle: The case from the Kaapvaal craton}

A comprehensive analysis of $\mathrm{H}_{2} \mathrm{O}$ content and formation pressure of peridotite xenoliths from the Kaapvaal craton in South Africa demonstrates vertical variations in $\mathrm{H}_{2} \mathrm{O}$ content in the lithospheric mantle of South Africa [38,91]. Figure 3 shows variations in formation pressure of peridotites versus the $\mathrm{H}_{2} \mathrm{O}$ content of ol, including the peridotite xenoliths that are hosted by kimberlites with both pressure estimates and the $\mathrm{H}_{2} \mathrm{O}$ contents of ol available [27,36-38,48]. Profile FTIR analyses have confirmed that the $\mathrm{H}_{2} \mathrm{O}$ content of these olivines preserved the source values and have not been affected by $\mathrm{H}$ loss during ascent. At $P<3 \mathrm{GPa}$ and $>6.5 \mathrm{GPa}$, the $\mathrm{H}_{2} \mathrm{O}$ content of ol are quite low $(<10$ ppm); at $P=3.5-5.5 \mathrm{GPa}$, the region is water-rich, and the $\mathrm{H}_{2} \mathrm{O}$ content of ol is $>100 \mathrm{ppm}$, which is much higher than the expected value of the olivines in the MORB source. Although the host magma of these peridotites erupted in the Mesozoic and even the Proterozoic (1202-86 Ma), this vertical distribution of $\mathrm{H}_{2} \mathrm{O}$ content of the lithospheric mantle is expected to be preserved after the host magma's eruption and reflects the present hydrous state of the Kaapvaal craton $[38,91]$. Considering elemental and radiogenic isotope characteristics, Peslier et al. [91] proposed that the waterrich layer in the central lithospheric mantle is the product of

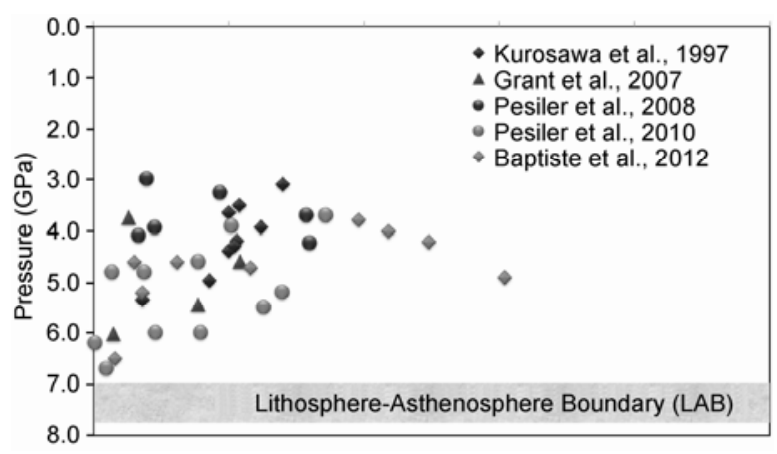

Figure 3 Formation pressure vs. $\mathrm{H}_{2} \mathrm{O}$ content of olivine in peridotite from Kaapvaal craton, South Africa. 
mantle metasomatic events that occurred in ArcheanProterozoic. This layer actually corresponds with the "metasome" layer revealed by petrological and geochemical studies and is believed to be the source of small-scale alkali magmas [30].

\subsection{Temporal variations of $\mathrm{H}_{2} \mathrm{O}$ content in the conti- nental lithospheric mantle: The case from the NCC}

The Early Cretaceous was the peak time of the NCC destruction [62]; the basalts derived from the Early Cretaceous lithospheric mantle therefore provide an opportunity to study the hydrous state of the Late Mesozoic NCC lithospheric mantle and make it possible to compare the Mesozoic and Cenozoic hydrous states of the lithospheric mantle.

Xia et al. [28] conducted a detailed analysis of the $\mathrm{H}_{2} \mathrm{O}$ content and chemical compositions of cpx phenocrysts in the $\sim 120 \mathrm{Ma}$ lithospheric mantle-derived high-Mg basalts erupted at Feixian, eastern NCC [92]. The measured $\mathrm{H}_{2} \mathrm{O}$ content of the earliest crystallized cpx phenocrysts ( $\mathrm{Mg \#}$ around 90) are 210-370 ppm, and the calculated $\mathrm{H}_{2} \mathrm{O}$ contents of the equilibrated basaltic magmas are $3.4 \pm 0.7 \mathrm{wt} \%$, using a partition coefficient between cpx and melt [94]. This value is much higher than that of MORBs $(0.1-0.3 \mathrm{wt} \%)$ [63-66], OIBs $(0.3-1.0 \mathrm{wt} \%)$ [64,66-70] and the back-arc basin basalts (BABB, 0.2-2.0 wt\%) [94-96], falling within the range of the island arc magmas (2.0-8.0 wt\%) [71-74]. The estimated $\mathrm{H}_{2} \mathrm{O}$ contents of the lithospheric mantle source are $>1000 \mathrm{ppm}$, much higher than that of Cenozoic lithospheric mantle of the NCC. The strongly water-rich characteristics of the late Mesozoic NCC lithospheric mantle are likely related to multi-stage subduction events by the surrounding oceanic plates since the Paleozoic [97]. Notably, the water-rich state of the Late Mesozoic corresponded

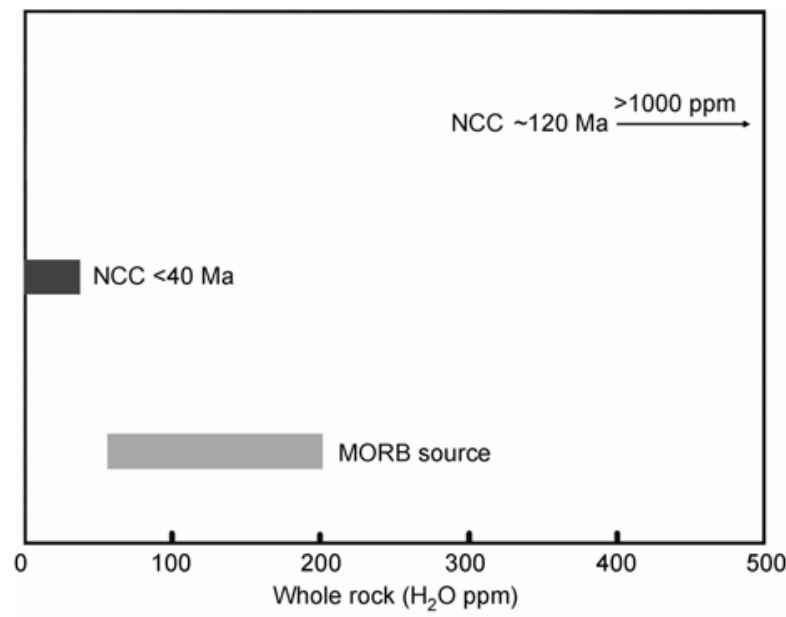

Figure 4 Comparison of $\mathrm{H}_{2} \mathrm{O}$ content of lithospheric mantle of the NCC in Mesozoic and Cenozoic. Data for the Mesozoic lithospheric mantle of the NCC are from [28], those for the Cenozoic lithospheric mantle of the NCC are from $[28,40,41]$, and those for the MORB source are from [63-66]. to the lithospheric thinning and craton destruction of the NCC, whereas the water-poor state of the Cenozoic corresponded to the time when the NCC lithospheric mantle regained stability.

The temporal and spatial distribution of $\mathrm{H}_{2} \mathrm{O}$ contents in the continental lithospheric mantle is most likely associated with a variety of factors [27,91], including the degree of partial melting and metasomatic overprint of rocks, crystal chemical characteristics of minerals, diversity of temperature, pressure, oxygen fugacity and water fugacity. Therefore, a systematic and combined examination of petrological (i.e. petrography, P-T conditions and even petrogenesis) and geochemical (i.e. major and trace elements and isotopic compositions) data for specific regions is needed to explore the heterogeneity of $\mathrm{H}_{2} \mathrm{O}$ contents. In addition, to make large-scale comparisons and understand the regional heterogeneity, tectonic environments and geophysical data need to be incorporated.

\section{Heterogeneity of $\mathrm{H}_{2} \mathrm{O}$ contents of the conti- nental lithospheric mantle and overlying lower crust}

Comparative studies [98-100] of peridotite xenoliths (representing the lithospheric mantle) and coexisting mafic granulite xenoliths (representing the lowest lower crust) hosted by the Cenozoic basalts from Nushan in Anhui Province, Hannuoba in Hebei Province and Junan in Shandong Province of the NCC have revealed significant differences in $\mathrm{H}_{2} \mathrm{O}$ contents between the lithospheric mantle and the overlying lower crust: the lower crust has much higher $\mathrm{H}_{2} \mathrm{O}$ content (Figure 5). Differences between the two layers may be related to their petrogeneses: the protoliths of mafic granulites were gabbros that were crystallized from basaltic melts, and peridotites are melting residues. The residues of melts would be strongly depleted in $\mathrm{H}_{2} \mathrm{O}$ due to the compound's incompatible behavior during the mantle melting processes [22,35]. When considering the impact of $\mathrm{H}_{2} \mathrm{O}$ on mineral/rock viscosity $[1,8,13]$, the strength of the lithosphere above and below the Moho should be decoupled [99]. The current data are limited in these three locations, and more observations are therefore needed to determine whether the contrast of the $\mathrm{H}_{2} \mathrm{O}$ content of the lithospheric mantle with that of the overlying lower crust is a common phenomenon in the global continental region.

\section{The relationship between the $\mathrm{H}_{2} \mathrm{O}$ content of the lithospheric mantle and continent stability}

The key factor controlling the stability of the continental lithosphere is the viscosity contrast at the lithosphereasthenosphere boundary (LAB) [56]. Due to the significant influence of $\mathrm{H}_{2} \mathrm{O}$ on mineral rheological strength $[1,8,13]$, 


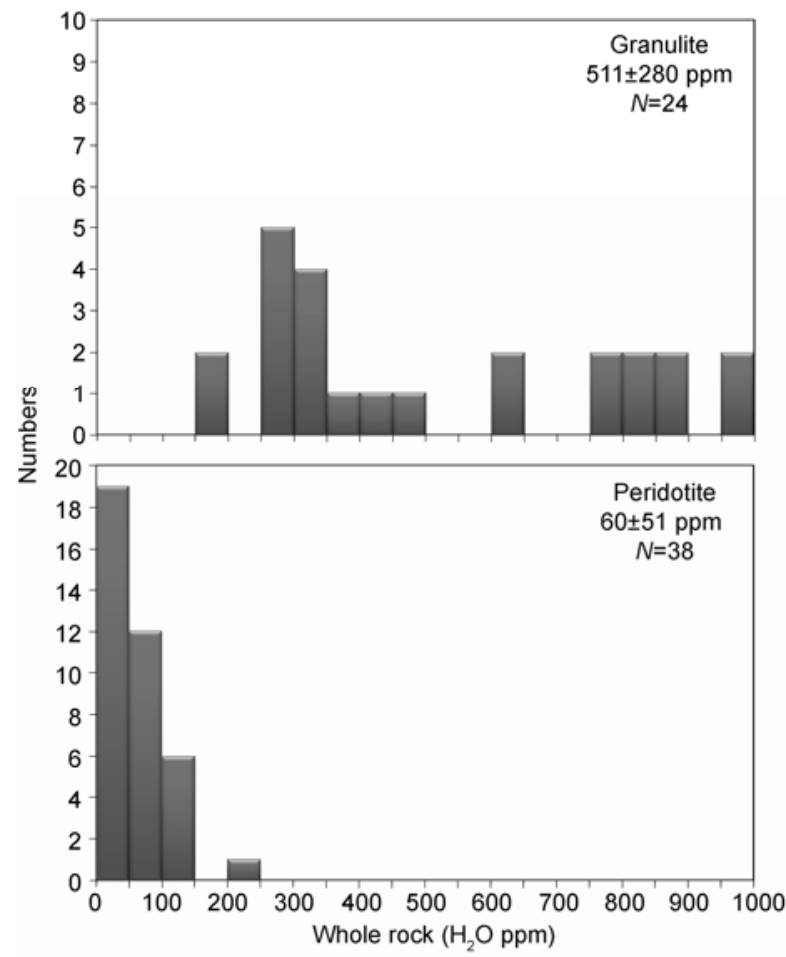

Figure 5 Comparison of $\mathrm{H}_{2} \mathrm{O}$ content of continental lithospheric mantle and overlying lower crust. Numbers in the figure are the average and standard deviation. Data are from [98-100].

the continental stability should be tightly related to the water content $[25,26]$. Because olivine is the dominant mineral in the lithospheric mantle and its strength is less than that of pyroxene, the strength of the lithospheric mantle is mainly controlled by ol. Figure 6 shows the correlation between the calculated viscosity based on olivine $\mathrm{H}_{2} \mathrm{O}$ content and lithosphere depth, using the Paleozoic geothermal gradient of the NCC [61]. The $\mathrm{H}_{2} \mathrm{O}$ contents of ol significantly affect the viscosity contrast between the lithosphere and asthenosphere. Recently, several case studies have connected the $\mathrm{H}_{2} \mathrm{O}$ content of ol from the lowermost lithospheric mantle with the stability of continents, using the LAB viscosity contrast calculated from the $\mathrm{H}_{2} \mathrm{O}$ content of ol and regional geothermal gradients.

Peslier et al. [27] conducted an FTIR analysis for ol in peridotites from the lowermost lithospheric mantle of the Kaapvaal craton and found that the $\mathrm{H}_{2} \mathrm{O}$ contents of ol are $<10$ ppm, which corresponds to a viscosity of the lithospheric mantle of 20 to $>3000$ times that of the asthenosphere (Figure 2 in [27]) and indicates that the long-term stable cratonic lithosphere indeed has high viscosity. This was the first study to directly connect the longevity of continents with the low $\mathrm{H}_{2} \mathrm{O}$ content of the lowermost lithospheric mantle.

Dixon et al. [19] combined the tectonic environment with geochemical and geophysical data and noted that the low viscosity of the western United States area could be due to the hydration of the upper mantle by long-term subduction

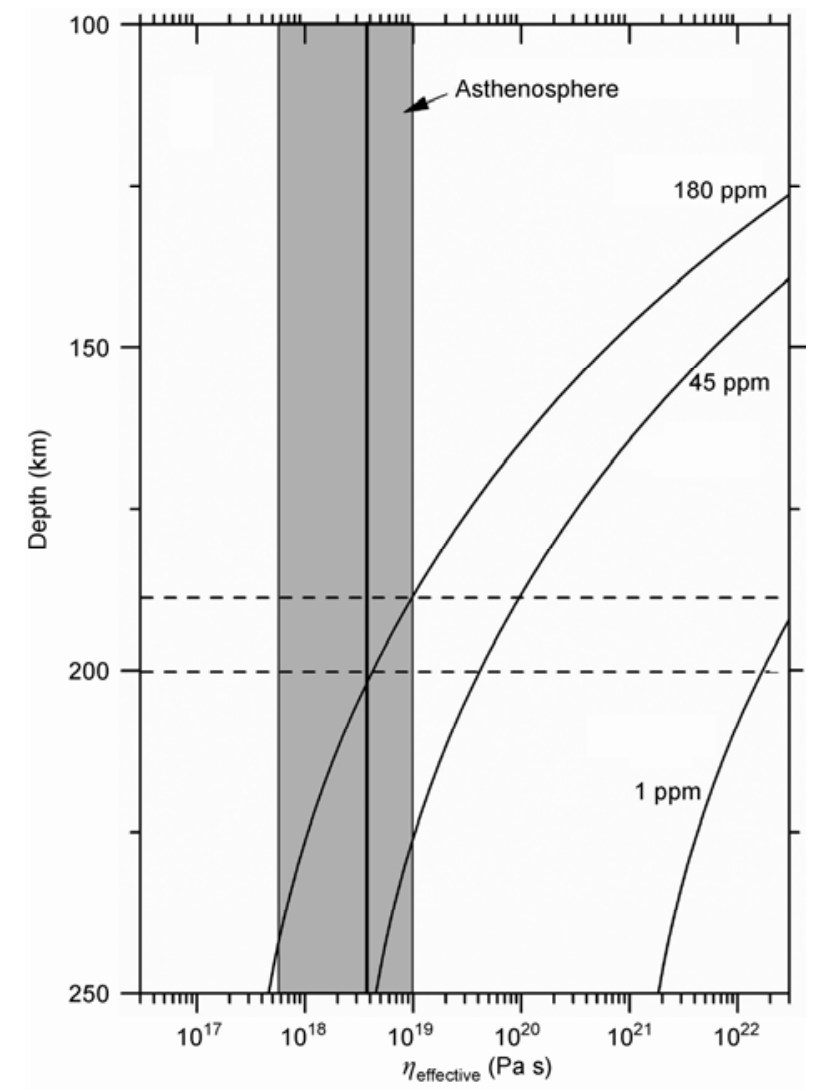

Figure 6 Effective viscosities with varieties of $\mathrm{H}_{2} \mathrm{O}$ content of olivine. (modified from [28]). The shaded area is the range and average of asthenosphere viscosity, and the numbers on top of the curve are the $\mathrm{H}_{2} \mathrm{O}$ contents of olivine.

of the Farallon plate. Using FTIR, Li et al. [23] directly measured the $\mathrm{H}_{2} \mathrm{O}$ content of peridotite minerals hosted by the Cenozoic basalts from the Colorado Plateau and its surrounding areas. The results show that these minerals contain much higher $\mathrm{H}_{2} \mathrm{O}$ content than the expected values in the asthenosphere and that the $\mathrm{H}_{2} \mathrm{O}$ content of ol in peridotites from the Colorado Plateau can have a value up to $45 \mathrm{ppm}$. These olivines experienced $\mathrm{H}$ loss by diffusion upon the xenolith ascent, so the measured $\mathrm{H}_{2} \mathrm{O}$ content only reflects the minimum values of the mantle source. Simulation results shows that, even with the minimum estimated $\mathrm{H}_{2} \mathrm{O}$ content of ol, the hydration process is also able to lower the viscosity of the lowermost lithosphere by an order of magnitude (Figure 9 in [23]). Thus, Li et al. [23] speculated that the hydration that caused lithosphere weakening might be an important mechanism in the lithospheric thinning in the Colorado Plateau.

An example that directly links hydration and lithospheric thinning (and craton destruction) is the study by Xia et al. [28]. Based on detailed analyses of $\sim 120$ Ma Feixian basalts from the NCC, they found that the $\mathrm{H}_{2} \mathrm{O}$ content of the early Cretaceous lithospheric mantle was $>1000$ ppm. Furthermore, they calculated the $\mathrm{H}_{2} \mathrm{O}$ content of ol in such lithospheric mantle to be $>180 \mathrm{ppm}$. The calculated viscosity 
based on the $\mathrm{H}_{2} \mathrm{O}$ content of ol demonstrates that the lowermost lithospheric mantle $(\sim 200 \mathrm{~km})[61,62]$ of the NCC at the early Cretaceous had a viscosity close to that of the asthenosphere (Figure 6). Regardless of the mechanisms of lithospheric thinning and NCC destruction, the reduced strength of the lithosphere by hydration is certainly an important premise. Because the Early Cretaceous was the peak time of NCC destruction, this study directly links the craton destruction with the reduced strength of lithospheric mantle by hydration.

\section{Future studies}

After nearly 20 years (though primarily the last decade) of endeavored studies of the hydrous state of the continental lithosphere, we have obtained some basic and structural knowledge about it, including the $\mathrm{H}_{2} \mathrm{O}$ occurrence, the range of $\mathrm{H}_{2} \mathrm{O}$ content, the partition of $\mathrm{H}_{2} \mathrm{O}$ among minerals, the spatial and temporal heterogeneity of $\mathrm{H}_{2} \mathrm{O}$ content, the complexity of factors controlling $\mathrm{H}_{2} \mathrm{O}$ content, and the geodynamic significance of the hydrous state. Studying the $\mathrm{H}_{2} \mathrm{O}$ content of mantle NAMs (then rocks) has extended from the mineralogical and mineral physical fields to geology, geochemistry, geophysics and geodynamics, and it has attracted growing interest. The pioneering paper by Bell and Rossman [31] on $\mathrm{H}_{2} \mathrm{O}$ content in mantle NAMs "Water in Earth's Mantle: Role of Nominally Anhydrous Minerals" has been cited more than 300 times in the last decade (2002-2012). Similarly, the paper by Hirth and Kohlstedt [16] "Water in the oceanic upper mantle: implications for rheology, melt extraction and the evolution of the lithosphere", which discussed the influence of mineral $\mathrm{H}_{2} \mathrm{O}$ content on mantle melting, rheology and lithosphere evolution, has been cited more than 560 times in the past decade (2002-2012). However, because our understanding in many fields is not comprehensive, future studies should focus on the following aspects.

\subsection{Accumulate more data on natural samples}

As described above, the data of peridotites from cratonic mantle are mainly from the Kaapvaal and Siberia cratons, and only garnet data and sporadic olivine data are available, while data from pyroxenes are absent. No data are available for other cratons, and the data for the sub-arc mantle remain sparse. Although there are off-craton samples from many regions, the sample numbers are insufficient to provide a statistically meaningful message, except in western North America. As to a single tectonic block, only the NCC has $\mathrm{H}_{2} \mathrm{O}$ content data covering nearly the entire geographic region with sufficient statistical means on the number of samples. The vertical heterogeneity of $\mathrm{H}_{2} \mathrm{O}$ distribution in the continental lithospheric mantle is only confirmed in the Kaapvaal craton. Moreover, the temporal heterogeneity of the $\mathrm{H}_{2} \mathrm{O}$ content in the continental lithospheric mantle is only observed in the eastern NCC between the late Mesozoic and Cenozoic. Undoubtedly, in the future, we need to accumulate more data from natural samples to develop a more meaningful understanding of the spatial and temporal distributions of the $\mathrm{H}_{2} \mathrm{O}$ content in the continental lithospheric mantle.

\subsection{Identify the parameters controlling $\mathrm{H}_{2} \mathrm{O}$ content}

We have realized that the factors affecting the $\mathrm{H}_{2} \mathrm{O}$ content of the lithospheric mantle are variable, including the mineral crystal chemistry, $\mathrm{H}_{2} \mathrm{O}$ solubility in the mineral under different physical and chemical conditions, and the $\mathrm{H}_{2} \mathrm{O}$ partition coefficient between minerals, as well as different geological processes during/after rock formation, even the evolution of the Earth. However, the degree of impact in different environments (including the physical and chemical states, geological processes and tectonic settings) of various factors and the possible affinity between factors and environments need further study. We need to strengthen the experimental studies of the complex systems so they are closer to the real mantle conditions and combine analysis of $\mathrm{H}_{2} \mathrm{O}$ content and other data (including petrology, geochemistry and geophysics) in natural samples to have a clear understanding of the parameters controlling the $\mathrm{H}_{2} \mathrm{O}$ content in the continental lithospheric mantle.

\subsection{Explore the potential for $\mathrm{H}_{2} \mathrm{O}$ as a tracer of geological processes}

In the mantle melting system, $\mathrm{H}_{2} \mathrm{O}$ has a partition coefficient close to $\mathrm{Ce}(\sim 0.01)[22,35]$, and it can be treated as an incompatible element. Like other trace elements (e.g. rare earth elements, large ion lithophile elements, and high field strength elements), the content, ratio, and isotope composition $(\mathrm{H}-\mathrm{O})$ can also be used as tracer of geological processes (e.g. partial melting, fractional crystallization, and metasomatism). The exploration in this direction is still preliminary [101].

Although the link between $\mathrm{H}_{2} \mathrm{O}$ content and continental stability is recognized, the specific mechanism, the process, and the spatial and temporal scales of influence are unclear. We need to strengthen the comparative analysis of $\mathrm{H}_{2} \mathrm{O}$ content and lithospheric mantle stability in different tectonic settings or different physical and chemical states to expand the research into the link between $\mathrm{H}_{2} \mathrm{O}$ and continental dynamics.

\subsection{Improve analytical methods of $\mathrm{H}_{2} \mathrm{O}$ measurement}

The methods for determining the water content of minerals, in addition to the generally adopted FTIR and ion probe, include vacuum extraction, nuclear reaction analysis (NRA), elastic reflection detection analysis (ERDA) and proton- 
proton scattering analysis (PPSA). Different methods sometimes give contradicting water content data, reflecting not only the limitations of the methods themselves but also the complexity of $\mathrm{H}$ cooperation mechanisms in minerals (e.g. point defects, line defects, planar defects, nano-scale inclusions). In future research, we need to improve the methods and choose the most suitable method based on different $\mathrm{H}$ cooperation mechanisms.

We thank Drs. Zheng Yongfei and Guo Zhengtang for inviting us to write this paper. Constructive review comments from Yang Xiaozhi and Zheng Jianpin are appreciated. This work was supported by the National Natural Science Foundation of China (91014007, 90714009 and 40673028).

1 Mackwell S J, Kohlstedt D L, Paterson M S. The role of water in the deformation of olivine single-crystals. J Geophys Res, 1985, 90: 1319-1333

2 Karato S, Paterson M S, FitzGerald J D. Rheology of synthetic olivine aggregates: Influence of grain size and water. J Geophys Res, 1986, 91: 8151-8176

3 Karato S. The role of hydrogen in the electrical conductivity of the upper mantle. Nature, 1990, 347: 272-273

4 Graham C M, Elphick S C. Some experimental constraints on the role of hydrogen in oxygen and hydrogen diffusion and Al-Si interdiffusion in silicates. In: Ganguly J, ed. Diffusion, Atomic Ordering, and Mass Transport. New York: Springer, 1991. 248-285

5 Meade C, Jeanloz R. Deep-focus earthquakes and recycling of water into the Earth's mantle. Science, 1991, 252: 68-72

6 Inoue T. Effect of water on melting phase relations and melt composition in the system $\mathrm{Mg}_{2} \mathrm{SiO}_{4}-\mathrm{MgSiO}_{3}-\mathrm{H}_{2} \mathrm{O}$ up to $15 \mathrm{GPa}$. Phys Earth Planet Inter, 1994, 85: 237-263

7 Hirose K. Melting experiments on lherzolite KLB-1 under hydrous conditions and generation of high-magnesian andesitic melts. Geology, 1997, 25: 42-44

8 Mei S, Kohlstedt D L. Influence of water on plastic deformation of olivine aggregates 2. Dislocation creep regime. J Geophys Res, 2000, 105: 21471-21481

9 Jung H, Karato S. Water-induced fabric transitions in olivine. Science, 2001, 293: 1460-1463

10 Hofmeister A M. Enhancement of radiative transfer in the upper mantle by $\mathrm{OH}^{-}$in minerals. Phys Earth Planet Inter, 2004, 146: 483495

11 Wang Z, Hiraga T, Kohlstedt D L. Effect of $\mathrm{H}^{+}$on Fe-Mg interdiffusion in olivine, $(\mathrm{Fe}, \mathrm{Mg})_{2} \mathrm{SiO}_{4}$. Appl Phys Lett, 2004, 85: 209-211

12 Hier-Majumder S, Anderson I M, Kohlstedt D L. Influence of protons on Fe-Mg interdiffusion in olivine. J Geophys Res, 2005, 110: B02202

13 Karato S. Rheology of the deep upper mantle and its implications for the preservation of the continental roots: A review. Tectonophysics, 2010, 481: 82-98

14 Gaetani G A, Grove T L, Bryan W B. The influence of water on the petrogenesis of subduction related igneous rocks. Nature, 1993, 365: 332-334

15 Hirose K, Kawamoto T. Hydrous partial melting of lherzolite at 1 GPa: The effect of $\mathrm{H}_{2} \mathrm{O}$ on the genesis of basaltic magmas. Earth Planet Sci Lett, 1995, 133: 463-473

16 Hirth G, Kohlstedt D L. Water in the oceanic upper mantle: Implications for rheology, melt extraction and the evolution of the lithosphere. Earth Planet Sci Lett, 1996, 144: 93-108

17 Gaetani G A, Grove T L. The influence of water on melting of mantle peridotite. Contrib Mineral Petrol, 1998, 131: 323-346

18 Asimow P D, Langmuir C H. The important of water to oceanic mantle melting regimes. Nature, 2003, 421: 815-820

19 Dixon J E, Dixon T H, Bell D R, et al. Lateral variation in upper mantle viscosity: Role of water. Earth Planet Sci Lett, 2004, 222 .
$451-467$

20 Hirschmann M M, Aubaud C, Withers A C. Storage capacity of $\mathrm{H}_{2} \mathrm{O}$ in nominally anhydrous minerals in the upper mantle. Earth Planet Sci Lett, 2005, 236: 167-181

21 Hirschmann M M, Tenner T, Aubaud C, et al. Dehydration melting of nominally anhydrous mantle: The primacy of partitioning. Phys Earth Planet Int, 2009, 176: 54-68

22 Hauri E H, Gaetani G A, Green T H. Partitioning of water during melting of the Earth's upper mantle at $\mathrm{H}_{2} \mathrm{O}$-undersaturated conditions. Earth Planet Sci Lett, 2006, 248: 715-734

23 Li Z X A, Lee C T, Peslier A H, et al. Water contents in mantle xenoliths from the Colorado Plateau and vicinity: Implications for the mantle rheology and hydration-induced thinning of continental lithosphere. J Geophys Res, 2008, doi: B0921010. 1029/2007jb005540

24 Grove T L, Till C B, Krawczynski M J. The role of $\mathrm{H}_{2} \mathrm{O}$ in subduction zone magmatism. Annu Rev Earth Planet Sci, 2012, 40: 413-439

25 Jordan T H. Composition and development of continental tectosphere. Nature, 1978, 274: 544-548

26 Pollack H N. Cratonization and thermal evolution of the mantle. Earth Planet Sci Lett, 1986, 80: 175-182

27 Peslier A H, Woodland A B, Bell D R, et al. Olivine water contents in the continental lithosphere and the longevity of cratons. Nature, 2010, 467: 78-U108

28 Xia Q K, Liu J, Liu S C, et al. High water content in Mesozoic primitive basalts of the North China Craton and implications for the destruction of cratonic mantle lithosphere. Earth Planet Sci Lett, 2013, 361: 85-97

29 Frezzotti M L, Ferrando S, Tecce F, et al. Water content and nature of solutes in shallow-mantle fluids from fluid inclusions. Earth Planet Sci Lett, 2012, 351-352: 70-83

30 Hawkesworth C, Rogers N, van Calsteren P, et al. Mantle enrichment processes and the origin of basalts. In: Mantle Metasomatism. London: Academic Press, 1987. 365-388

31 Bell D R, Rossman G R. Water in Earth's mantle: The role of nominally anhydrous minerals. Science, 1992, 255: 1391-1397

32 Ingrin J, Skogby H. Hydrogen in nominally anhydrous upper-mantle minerals: Concentration levels and implications. Eur J Mineral, 2000, 12: 543-570

33 Bell D R, Ihinger P D, Rossman G R. Quantitative analysis of trace $\mathrm{OH}$ in garnet and pyroxenes. Am Mineral, 1995, 80: 465-474

34 Bell D R, Rossman G R, Maldener J, et al. Hydroxide in olivine: A quantitative determination of the absolute amount and calibration of the IR spectrum. J Geophys Res, 2003, 108: 2105

35 Green D H, Hibberson W O, Kovács I, et al. Water and its influence on the lithosphere-asthenosphere boundary. Nature, 2010, 467: 448451

36 Grant $\mathrm{K}$, Ingrin J, Lorand J P, et al. Water partitioning between mantle minerals from peridotite xenoliths. Contrib Mineral Petrol, 2007, 154: 15-34

37 Peslier A H, Woodland A B, Wolff J A. Fast kimberlite ascent rates estimated from hydrogen diffusion profiles in xenolithic olivines from Southern Africa. Geochim Cosmochim Acta, 2008, 72: 27112722

38 Baptiste V, Tommasi A, Demouchy S. Deformation and hydration of the lithospheric mantle beneath the Kaapvaal craton, South Africa. Lithos, 2012, doi:10.1016/j.lithos.2012.05.001

39 Peslier A H, Luhr J F, Post J. Low water contents in pyroxenes from spinel-peridotites of the oxidized, sub-arc mantle wedge. Earth Planet Sci Lett, 2002, 201: 69-86

40 Xia Q K, Hao Y T, Li P, et al. Low water content of the Cenozoic lithospheric mantle beneath the eastern part of the North China Craton. J Geophys Res, 2010, 115: B07207

41 Hao Y T, Xia Q K, Zhang Y P, et al. Recognizing juvenile and relict lithospheric mantle beneath the North China Craton: Combined analysis of $\mathrm{H}_{2} \mathrm{O}$, major and trace elements and $\mathrm{Sr}-\mathrm{Nd}$ isotope compositions of clinopyroxenes. Lithos, 2012, 149: 136-145

42 Demouchy S, Jacobsen S D, Gaillard F, et al. Rapid magma ascent recorded by water diffusion profiles in mantle olivine. Geology, 2006, 34: 429-432 
43 Peslier A H, Luhr J F. Hydrogen loss from olivines in mantle xenoliths from Simocoe (USA) and Mexico: Mafic alkalic magma ascent rates and water budget of the sub-continental lithosphere. Earth Planet Sci Lett, 2006, 242: 302-319

44 Xia Q K, Hao Y T, Liu S C, et al. Water contents of the Cenozoic lithospheric mantle beneath the western part of the North China Craton: Peridotite xenolith constraints. Gondwana Res, 2013, 23: $108-118$

45 Aubaud C, Withers A C, Hirschmann M M, et al. Intercalibration of FTIR and SIMS for hydrogen measurements in glasses and nominally anhydrous minerals. Am Mineral, 2007, 92: 811-828

46 Tenner T J, Hirschmann M M, Withers A C, et al. Hydrogen partitioning between nominally anhydrous upper mantle minerals and melt between 3 and $5 \mathrm{GPa}$ and applications to hydrous peridotite partial melting. Chem Geol, 2009, 262: 42-56

47 Bell D R, Rossman G R. The distribution of hydroxyl in garnets from the subcontinental mantle in southern Africa. Contrib Mineral Petrol, 1992, 111: 161-178

48 Kurosawa M, Yurimoto $\mathrm{H}$, Sueno S. Patterns in the hydrogen and trace element compositions of mantle olivines. Phys Chem Mineral, 1997, 24: 385-395

49 Kent A J R, Rossman G R. Hydrogen, lithium, and boron in mantle-derived olivine: The role of coupled substitutions. Am Mineral, 2002, 87: 1432-1436

50 Matsyuk S S, Langer K, Hosch A. Hydroxyl defects in garnets from mantle xenoliths in kimberlites of the Siberian platform. Contrib Mineral Petrol, 1998, 132: 163-179

51 Matsyuk S S, Langer K. Hydroxyl in olivines from mantle xenoliths in kimberlites of the Siberian platform. Contrib Mineral Petrol, 2004, 147: 413-437

52 Skogby H, Bell D R, Rossman G R. Hydroxide in pyroxene: Variations in the natural-environment. Am Mineral, 1990, 75: 764-774

53 Mosenfelder J L, Sharp T G, Asimow P D, et al. Hydrogen incorporation in natural mantle olivines. In: Jacobsen S, Lee S, eds. Earth's Deep Water Cycle: AGU, Washington D C, 2006. 1527-1541

54 Bonadiman C, Hao Y, Coltorti M, et al. Water contents of pyroxenes in intraplate lithospheric mantle. Eur J Mineral, 2009, 21: 637-647

55 Carlson R W, Pearson D G, James D E. Physical, chemical, and chronological characteristics of continental mantle. Rev Geophys, 2005, 43: 24

56 Lee C T, Luggi P, Chin E J. Building and destroying continental mantle. Annu Rev Earth Planet Sci, 2011, 39: 59-90

57 Smith D. Insights into the evolution of the uppermost continental mantle from xenolith localities on and near the Colorado Plateau and regional comparisons. J Geophys Res, 2000, 105: 16769-16781

58 Lee C T, Yin Q, Rudnick R L, et al. Preservation of ancient and fertile lithospheric mantle beneath the southwestern United States. Nature, 2001, 411: 69-73

59 Humphreys E D, Hessler E, Dueker K G, et al. How Laramide-age hydration of North American lithosphere by the Farallon slab controlled subsequent activity in the western United States. Int Geol Rev, 2003, 45: 575-595

60 West M, Ni J, Baldridge W S, et al. Crust and upper mantle shear wave structure of the southwest United States: Implications for rifting and support for high elevation. J Geophys Res, 2004, 109: B03309

61 Griffin W L, Zhang A D, O'Reilly S Y, et al. Phanerozoic evolution of the lithosphere beneath the Sino-Korean craton. In: Flower F M J, Chung S L, Lo C H, et al. Mantle Dynamics and Plate Interactions in East Asia. Geodynamic Series: AGU, Washington D C, 1998, 27: 107-126

62 Menzies M A, Xu Y G, Zhang H F, et al. Integration of geology, geophysics and geochemistry: A key to understanding the North China Craton. Lithos, 2007, 96: 1-21

63 Michael P J. The concentration, behavior and storage of $\mathrm{H}_{2} \mathrm{O}$ in the suboceanic upper mantle: Implications for mantle metasomatism. Geochim Cosmochim Acta, 1988, 52: 555-566

64 Sobolev A V, Chaussidon $\mathrm{M}$. $\mathrm{H}_{2} \mathrm{O}$ concentrations in primary melts from supra-subduction zones and mid-ocean ridges: Implications for $\mathrm{H}_{2} \mathrm{O}$ storage and recycling in the mantle. Earth Planet Sci Lett, 1996,
137: 45-55

65 Saal A E, Hauri E H, Langmuir C H, et al. Vapor undersaturation in primitive mid-ocean-ridge basalt and the volatile content of Earth's upper mantle. Nature, 2002, 419: 451-455

66 Simons K, Dixon J, Schilling J G, et al. Volatiles in basaltic glasses from the Easter-Salas y Gomez Seamount Chain and Easter Microplate: Implications for geochemical cycling of volatile elements. Geochem Geophys Geosyst, 2002, 3: 1-29

67 Dixon J E, Clague D A, Wallace P, et al. Volatiles in alkalic basalts from the North Arch Volcanic Field, Hawaii: Extensive degassing of deep submarine-erupted alkalic series lavas. J Petrol, 1997, 38: 911939

68 Wallace P J. Water and partial melting in mantle plumes: Inferences from the dissolved $\mathrm{H}_{2} \mathrm{O}$ concentrations of Hawaiian basaltic magmas. Geophys Res Lett, 1998, 25: 3639-3642

69 Nichols A R L, Carroll M R, Höskuldsson Á. Is the Iceland hot spot also wet? Evidence from the water contents of undegassed submarine and subglacial pillow basalts. Earth Planet Sci Lett, 1999, 202: 77-87

70 Dixon J E, Clague D A. Volatiles in basaltic glasses from Loihi Seamount, Hawaii: Evidence for a relatively dry plume component. J Petrol, 2001, 42: 627-634

71 Sisson T W, Grove T L. Temperature and $\mathrm{H}_{2} \mathrm{O}$ contents of low-MgO high-alumina basalts. Contrib Mineral Petrol, 1993, 113: 167-184

72 Sisson T W, Layne G D. $\mathrm{H}_{2} \mathrm{O}$ in basalt and basaltic andesite glass inclusions from four subduction-related volcanoes. Earth Planet Sci Lett, 1993, 117: 619-635

73 Dobson P F, Skogby H, Rossman G R. Water in boninite glass and coexisting orthopyroxene: Concentration and partitioning. Contrib Mineral Petrol, 1995, 118: 414-419

74 Wallace P J. Volatiles in subduction zone magmas: Concentrations and fluxes based on melt inclusion and volcanic gas data. J Volcano Geotherm Res, 2005, 140: 217-240

$75 \mathrm{Yu} \mathrm{Y,} \mathrm{Xu}$ X, Griffin W L, et al. $\mathrm{H}_{2} \mathrm{O}$ contents and their modification in the Cenozoic subcontinental lithospheric mantle beneath the Cathaysia block, SE China. Lithos, 2011, 126: 182-197

76 Fan Q C, Hooper P R. The mineral chemistry of ultramafic xenoliths of Eastern China-Implications for upper mantle composition and paleogeotherms, J Petrol, 1989, 30: 1117-1158

77 Xu X S, O'Reilly S Y, Griffin W L, et al. A xenolith-derived geotherm and the crust/mantle boundary at Qilin, southeastern China. Lithos, 1996, 38: 41-62

78 Xu X S, O'Reilly S Y, Griffin W L, et al. Genesis of young lithospheric mantle in SE China. J Petrol, 2000, 41: 111-148

79 Xu X S, O'Reilly S Y, Griffin W L, et al. Enrichment of upper mantle peridotite: Petrological, trace element and isotopic evidence in xenoliths from SE China. Chem Geol, 2003, 198: 163-188

80 Zheng J P, O'Reilly S Y, Griffin W L, et al. Nature and evolution of Cenozoic lithospheric mantle beneath Shandong Peninsula, SinoKorea craton, eastern China. Inter Geol Rev, 1998, 40: 471-499

81 Zheng J P, O'Reilly S Y, Griffin W L, et al. Relict refractory mantle beneath the easern North China Block: Significance for lithospheric evolution. Lithos, 2001, 57: 43-66

82 Zheng J P, Griffin W L, O'Reilly S Y, et al. Mineral chemistry of peridotites from Paleozoic, Mesozoic and Cenozoic lithosphere: Constraints on mantle evolution beneath eastern China. J Petrol, 2006, 47: 2233-2256

83 Fan W M, Zhang H F, Baker J, et al. On and off the north China craton: Where is the Archean keel? J Petrol, 2000, 41: 933-950

84 Gao S, Rudnick R L, Carlson R W, et al. Re-Os evidence for replacement of ancient mantle lithosphere beneath the North China craton. Earth Planet Sci Lett, 2002, 198: 307-322

85 Rudnick R L, Gao S, Ling W L, et al. Petrology and geochemistry of spinel peridotite xenoliths from Hannuoba and Qixia, North China craton, Lithos, 2004, 77: 609-637

86 Reisberg L, Zhi X C, Lorang J P, et al. Re-Os and S systematics of spinel peridotite xenoliths from east central China: Evidence for contrasting effects of melt percolation. Earth Planet Sci Lett, 2005, 239: 286-308

87 Wu F Y, Walker R J, Yang Y H, et al. The chemical-temporal evolu- 
tion of lithospheric mantle underlying the North China Craton. Geochim Cosmochim Acta, 2006, 70: 5013-5034

88 Ying J F, Zhang H F, Kita N, et al. Nature and evolution of Late Cretaceous lithospheric mantle beneath the eastern North China Craton: Constraints from petrology and geochemistry of peridotitic xenoliths from Junan, Shandong Province, China. Earth Planet Sci Lett, 2006, 244: 622-638

89 Xu Y G, Blusztajn J, Ma J L, et al. Late Archean to Early Proterozoic lithospheric mantle beneath the western North China craton: Sr-NdOs isotopes of peridotite xenoliths from Yangyan and Fansi. Lithos, 2008, 102: 25-42

90 Zhang H F, Goldstein S L, Zhou X H, et al. Comprehensive refertilization of lithospheric mantle beneath the North China Craton: Further Os-Sr-Nd isotopic constraints. J Geol Soc, 2009, 166: 249-259

91 Peslier A H, Woodland A B, Bell D R, et al. Metasomatic control of water contents in the Kaapvaal cratonic mantle. Geochim Cosmochim Acta, 2012, 97: 213-246

92 Gao S, Rudnick R L, Xu W L, et al. Recycling deep cratonic lithosphere and generation of intraplate magmatism in the North China Craton. Earth Planet Sci Lett, 2008, 270: 41-53

93 O'Leary J A, Gaetani G A, Hauri E H. The effect of tetrahedral $\mathrm{Al}^{3+}$ on the partitioning of water between clinopyroxene and silicate melt. Earth Planet Sci Lett, 2010, 297: 111-120

94 Hochstaedter A G, Gill J B, Kusakabe M, et al. Volcanism in the
Sumisu rift: I. Major element, volatile, and stable isotope geochemistry, the Mariana Trough. Earth Planet Sci Lett, 1990, 100: 179-194

95 Danyushevsky L V, Falloon T J, Sobolev A V, et al. The $\mathrm{H}_{2} \mathrm{O}$ content of basalt glasses from southwest Pacific backarc basins. Earth Planet Sci Lett, 1993, 117: 347-362

96 Stolper E, Newman S. The role of water in the petrogenesis of Mariana trough magmas. Earth Planet Sci Lett, 1994, 121: 293-325

97 Windley B F, Maruyama S, Xiao W J. Delamination/thinning of subcontinental lithospheric mantle under Eastern China: The role of water and multiple subduction. Am J Sci, 2010, 310: 1250-1293

98 Yang X Z, Xia Q K, Deloule E, et al. Water in minerals of the continental lithospheric mantle and overlying lower crust: A comparative study of peridotite and granulite xenoliths from the North China Craton. Chem Geol, 2008, 256: 33-45

99 Yang X Z, Deloule E, Xia Q K, et al. Water contrast between Precambrian and Phanerozoic continental lower crust in eastern China. J Geophys Res, 2008, 113: B08207

100 Yang G C, Yang X Z, Hao Y T, et al. Water content difference between continental lower crust and lithospheric mantle: Granulite and peridotite xenoliths hosted in basalt from Junan, Shandong Province (in Chinese). Acta Petrol Mineral, 2012, 5: 691-700

101 Dixon J E, Leist L, Langmuir C, et al. Recycled dehydrated lithosphere observed in plume-influenced mid-ocean-ridge basalt. Nature, 2002, 420: 385-389

Open Access This article is distributed under the terms of the Creative Commons Attribution License which permits any use, distribution, and reproduction in any medium, provided the original author(s) and source are credited. 